\title{
CONF-970582--1
}

\section{Thermal Behavior of Mixtures of Perlite and Phase Change Material in a Simulated Climate}

Thomas W. Petrie

Phillip W. Childs

Jeffrey E. Christian

Energy Division

Oak Ridge National Laboratory

Kenneth W. Childs

Computational Physics \& Engineering Division

Oak Ridge National Laboratory

Daniel J. Shramo

Phase Change Technologies, Inc.

Box 97433

Las Vegas, Nevada
RECEIVED SEP 191996

OSTI

To be presented and published in the

Insulation Materials: Testing and Applications: Third Volume ASTM STP 1320 (American Society for Testing and Materials)

Quebec City

May 15, 1997

Research sponsored by the Office of Building Technologies and

Department of Energy

\begin{abstract}
The submitted manuscript has been authored by a contractor of the U.S.

Government under contract No. DE-

AC05-96OR22464. Accordingly, the U.S.

Government retains a nonexclusive,

royalty-free license to publish or reproduce

the published form of this contribution, or

allow others to do so, for U.S. Government

purposes.
\end{abstract}

Prepared by the

OAK RIDGE NATIONAL LABORATORY

Oak Ridge, Tennessee 37831

managed by

LOCKHEED MARTIN ENERGY RESEARCH CORP.

for the

U.S. DEPARTMENT OF ENERGY

under contract No. DE-AC05-96OR22464 


\section{DISCLAIMER}

This report was prepared as an account of work sponsored by an agency of the United States Government. Neither the United States Government nor any agency thereof, nor any of their employees, make any warranty, express or implied, or assumes any legal liability or responsibility for the accuracy, completeness, or usefulness of any information, apparatus, product, or process disclosed, or represents that its use would not infringe privately owned rights. Reference herein to any specific commercial product, process, or service by trade name, trademark, manufacturer, or otherwise does not necessarily constitute or imply its endorsement, recommendation, or favoring by the United States Government or any agency thereof. The views and opinions of authors expressed herein do not necessar. ily state or reflect those of the United States Government or any agency thereof. 


\section{DISCLAMMER}

Portions of this document may be illegible in electronic image products. Images are produced from the best available original document. 
Thomas W. Petrie', Kenneth W. Childs ${ }^{2}$, Phillip W. Childs ${ }^{3}$, Jeffrey E. Christian ${ }^{4}$ and Daniel J. Shramos

\title{
THERMAL BEHAVIOR OF MIXTURES OF PERLITE AND PHASE CHANGE MATERIAL IN A SIMULATED CLIMATE
}

REFERENCE: Petrie, T.W., Childs, K.W., Childs, P.W., Christian, J.E., Shramo, D.J., "Thermal Behavior of Mixtures of Perlite and Phase Change Material in a Simulated Climate", Insulation Materials: Testing and Applications: Third Volume, ASTM STP 1320, R.S. Graves and R.R. Zarr, Eds., American Society for Testing and Materials, Philadelphia, 1997.

\begin{abstract}
A new concept for use of phase change material (PCM) in building envelopes has been investigated. The concept is called a RCR system in analogy to an electrical circuit with a capacitor between two resistors. Here, the thermal capacitance of the PCM is sandwiched between the thermal resistance of conventional insulation. The PCM used was hydrated calcium chloride dispersed in perlite and contained in watertight test cells. One cell had a PCM/perlite ratio of 2:1 by weight; the other had a 6:1 mixture. Extruded polystyrene (XPS) was the insulation below and above the PCM. Heat-flux transducers on the top and bottom of each cell as well as thermocouples from the top to the bottom of each cell allowed us to follow closely the progression of freezing and melting in the PCM as we subjected the cells to both steady and diurnally varying simulated outside temperatures. Computer modeling with a transient heat conduction program was successful in proving that we understood the relevant energy transfer mechanisms and thermophysical properties. For the diurnal cycles, with twice the amount of XPS below as above the PCM, much of the energy stored during daytime by melting PCM flowed to the outside at night when it froze again. Comparisons were made to the behavior of conventional insulation. With PCM, the total daily energy flow into the conditioned space below the test cells was lower and the peak flow rate was delayed in time and decreased in magnitude.
\end{abstract}

\footnotetext{
14 Development Staff Engineer, Energy Division; Group Leader, Computational Physics and Engineering Division; Staff Engineer, Energy Division; and, Program Manager, Energy Division, respectively, Oak Ridge National Laboratory, Oak Ridge, TN. ${ }^{5}$ Technical Director, Phase Change Technologies, Inc., Box 97433, Las Vegas, NV.
} 
KEYWORDS: Phase change material; Thermal control; Thermal mass; Calcium chloride; Peak load management

\section{INTRODUCTION}

The thermal benefits of phase change material (PCM) in building envelopes have been recognized for a long time. In the 1970s and 1980s, activity focused on development of suitable materials [1] and configurations $[2,3]$ to absorb solar energy during periods of peak solar insolation and release it gradually during off-peak periods or during nighttime to the conditioned space or to heat exchange equipment serving it. Materials were developed with properties tailored to building heating and cooling requirements. For example, in heating, materials could be selected with phase change temperatures that are a few degrees above room temperature. Latent energies of melting and freezing exceeded $233 \mathrm{~kJ} / \mathrm{kg}$ so that reasonable weights of materials could serve an entire building without severe changes in the design of structural supports. Architectural design changes were needed, of course, to allow sunlight to strike the phase change materials.

We are also interested in packaging PCM conveniently and efficiently for use in building envelopes. Our focus is on how to configure a PCM with other building envelope materials for thermal performance enhancement during building cooling by conventional means rather than for active thermal storage as part of solar heating. Phase change material is used with conventional insulation on both sides of it. It absorbs thermal energy directed toward the conditioned space and releases the stored energy to the ambient environment during nighttime hours. The proposed configuration is termed RCR in analogy to two electrical resistances with a capacitor between them.

The tests described here were performed in a large scale climate simulator (LSCS) at a national laboratory. The LSCS allows conditions of temperature and humidity to be imposed above horizontal test sections to simulate outdoor conditions ranging from extreme winter to extreme summer climates. Corresponding indoor conditions can be set below the test sections. For this work, the outdoor conditions were varied to simulate diurnal variations as well as constant temperatures. The latter forced the phase change materials to progressively melt or freeze completely so we could see their total potential for latent heat effects.

\section{APPARATUS AND PROCEDURES}

The objective of the tests in the LSCS was to understand the behavior of two mixtures of phase change material in perlite with foam insulation above and below the mixtures. We sought data to do engineering design of a candidate system for a whole building test. The computer program HEATTNG [4] was used to predict heat fluxes into and out of the candidate configurations for comparison to our measurements of these heat 
fluxes. Boundary conditions were the temperatures measured in the tests above and below the phase change material. The success of the modeling is important for identifying the relevant properties of a system with PCM to obtain enhanced thermal performance of the building envelope.

Two test cells were constructed to contain the different mixtures of phase change material and perlite. Perlite is a granular conventional insulation material that provided a convenient means to control and disperse the amount of PCM in the test cells. The PCM was a hydrated calcium chloride and was very hygroscopic so vapor-tight sealing of the test cells was imperative. One test cell contained a ratio of $2: 1 \mathrm{PCM}$ to perlite on a weight basis; the other had a $6: 1$ ratio. The $2: 1$ mixture was easy to handle. When exposed to the laboratory air, it formed some soft lumps, but they were easily crushed by hand. The 6:1 mixture, on the other hand, was difficult to handle. It formed hard lumps that had to be pulverized with a hammer to get a pourable mixture for its test cell.

Figure 1 shows the construction details of the $51 \mathrm{~cm}$ square by $5.1 \mathrm{~cm}$ high test cells. The construction material was $3.2 \mathrm{~mm}$ thick methylmethacrylate because it could be formed into a transparent and water impermeable box. The sides and bottoms were joined to each other by applying solvent along the seams. Pieces of methylmethacrylate also formed the tops of the cells. They were cut to loosely fit inside the sides and were sealed and held against the top of the PCM/perlite mixture in each box by wide plastic tape stretched tightly.

The precise pattern of holes enlarged at the right of Fig. 1 was drilled into the sides before joining and was used to locate $0.508 \mathrm{~mm}$ Nichrome support wires which held 30 gauge thermocouples. Three thermocouples were attached to each support wire, at the center and at $2.54 \mathrm{~cm}$ on both sides of center. The support wires were $0.51 \mathrm{~cm}$ apart vertically. They were pulled tight around screws which acted as anchor posts at the ends of the box. The $45^{\circ}$ slope of the pattern kept thermocouples at least $1.02 \mathrm{~cm}$ apart physically. In each box, three more thermocouples were attached to the center and at 2.54 $\mathrm{cm}$ on both sides of it on the insides of the bottom and the top, respectively. Averages of the temperatures at each level gave the temperature profile through the $\mathrm{PCM}$ /perlite mixtures. Two thermocouples were also placed along the center of the box

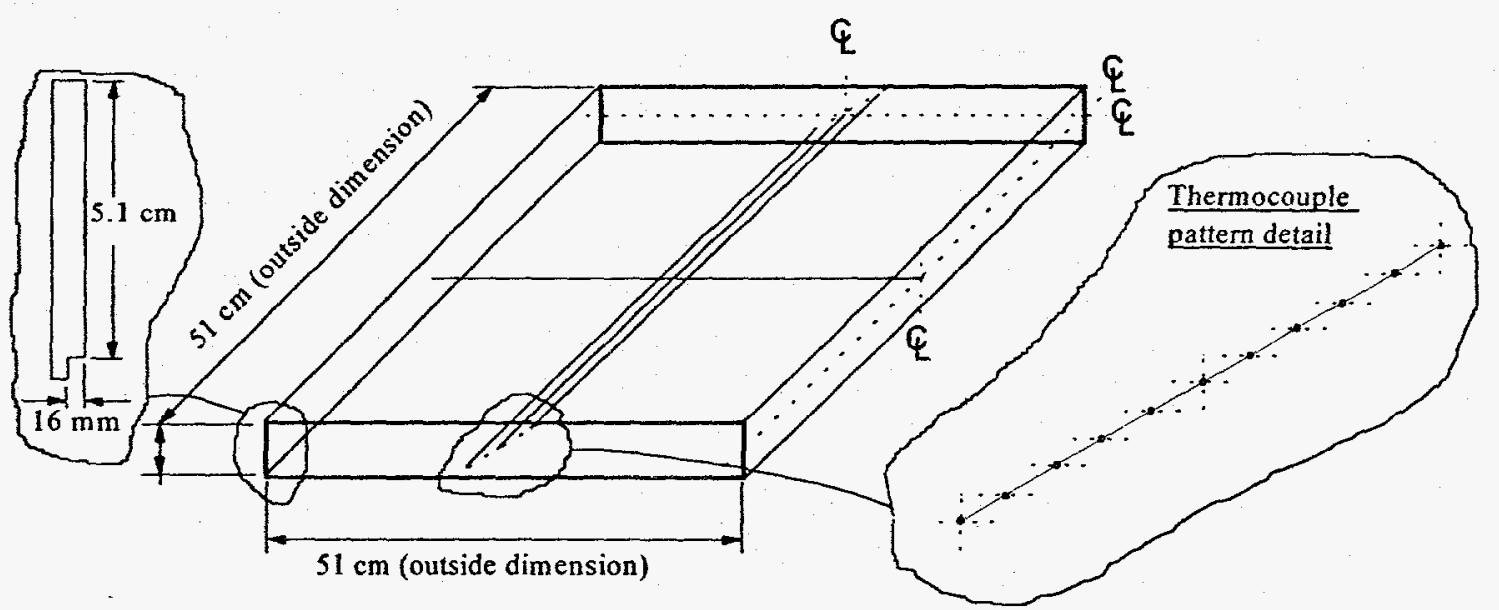

Fig. 1. Construction details of the test cells for the PCM/perlite mixtures. 
$1.27 \mathrm{~cm}$ and $2.54 \mathrm{~cm}$, respectively, in from each of the four sides to document that there was no significant temperature change from the centerline to the edge in each direction.

Squares for thin $5.08 \mathrm{~cm} \times 5.08 \mathrm{~cm}$ heat-flux transducers (HFTs) were routed out of the centers of the outsides of the bottom and top of each box. Only a paper-thin layer of methylmethacrylate was left between the HFTs and the PCM/perlite mixtures. Thus the HFTs measured the heat fluxes virtually on the surfaces of the mixtures.

The test cells were each placed on two squares of $1.3 \mathrm{~cm}$ thick pieces of extruded polystyrene (XPS) and covered by a single piece of the same thickness. This resulted in a $2: 1$ ratio between the thermal resistance below and above the cells. The $2: 1$ ratio was suggested by past experience to allow heat to escape from the top of the cells while preventing much from flowing into the space under the cells during the nighttimes of diurnal cycles.

The cells with XPS insulation above and below them fit between the $0.61 \mathrm{~m}$ on center ceiling joists of a manufactured home test section for the LSCS. Slots were cut in the two layers of fiberglass batt insulation in the space between the joists either side of the center space. The instrumentation in the center space was left in place and consisted of HFTs on the bottom of the bottom layer of fiberglass and thermocouples next to the HFTs and above them on top of the top layer of fiberglass. This instrumentation allowed us to follow the thermal behavior of the fiberglass batts while the test cells were being put through the series of tests to characterize the $\mathrm{PCM}$ /perlite mixtures and understand the behavior of the two configurations.

Figure 2 is a sketch of the test cells with XPS layers above and below them in place between the ceiling joists of the manufactured home test section in spaces on both sides of the center space. The test cells with the XPS layers above and below were not quite as thick as the fiberglass batt insulation. Without phase change occurring in the test cells, each assembly had about the same steady-state $\mathrm{R}$-value as the fiberglass batts. The test cells behave very differently from conventional fiberglass batts, however, while phase change is occurring in them. Physical dimensions, density and $\mathrm{R}$-value are not adequate for thermal characterization of the candidate configurations. Specific heat, including augmentation to account for phase change effects, is an essential parameter.

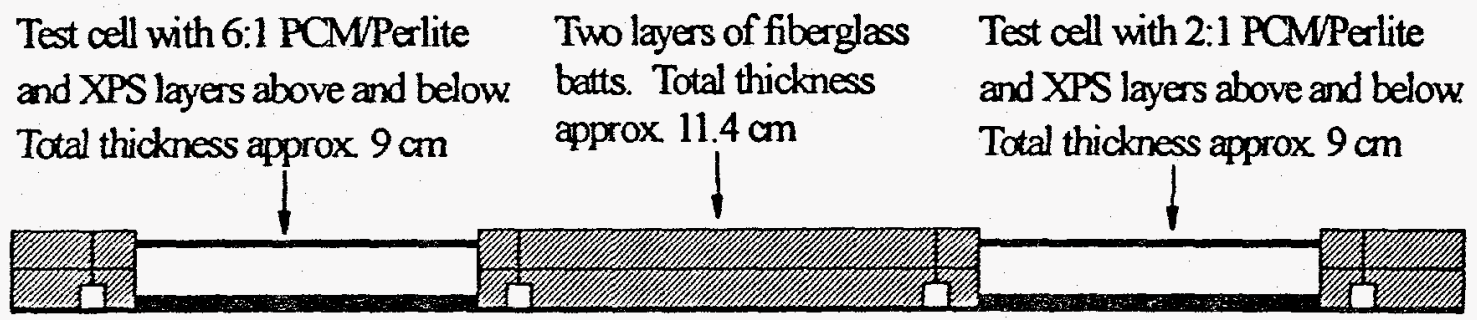

$0.95 \mathrm{~cm}$ thick gypsum board under $3.8 \times 3.8 \mathrm{~cm}$ ceiling joists $61 \mathrm{~cm}$ on center

Fig. 2. Schematic of test cells in place in the manufactured home test section. 


\section{MELT AND FREEZE RESULTS}

After the test cells were assembled, filled with their respective PCM/perlite mixtures and installed in the manufactured home test section, several days were spent with the upper and lower chambers of the LSCS at $24^{\circ} \mathrm{C}$ to achieve complete freezing of all PCM in the test cells. The upper (climate) chamber temperature was then rapidly brought to $52^{\circ} \mathrm{C}$ and held constant. The lower (metering) chamber temperature was held constant at $24^{\circ} \mathrm{C}$ for all the tests. Figure 3 shows temperatures and heat fluxes for the test cell containing the $2: 1 \mathrm{PCM}$ /perlite mixture over the next 70 hours as the PCM in it proceeded from completely frozen to completely melted. The climate chamber temperature history is included showing that the step change from $24^{\circ} \mathrm{C}$ to $52^{\circ} \mathrm{C}$ was rapid and smooth. The 6:1 mixture behaved similarly but took over twice as long to show the rapid rise of the bottom heat flux, which signifies the end of phase change in the test cell.

Positive heat fluxes mean that heat is flowing into the top or out the bottom of the cell. The HFTs were deliberately oriented for this effect. The top and bottom heat fluxes for the $2: 1$ mixture become equal before $60 \mathrm{~h}$ into the test and the phase change is essentially complete by $43 \mathrm{~h}$ when the bottom heat flux begins to rise rapidly. In both cells, the heat flux out the bottom was small and essentially constant while phase change was occurring because unmelted material at the melting temperature shielded the bottom heat flux transducer, causing a very small difference in temperatures between it and the chamber below at $24^{\circ} \mathrm{C}$.

The top heat flux and the temperature profiles in Fig. 3 show the complicated nature of the phase change for this PCM. As the phase change front proceeds from top to bottom of the cell, the upper layers melt and their temperatures rise. Thus, the top heat flux decreases because of the smaller temperature difference between the chamber above

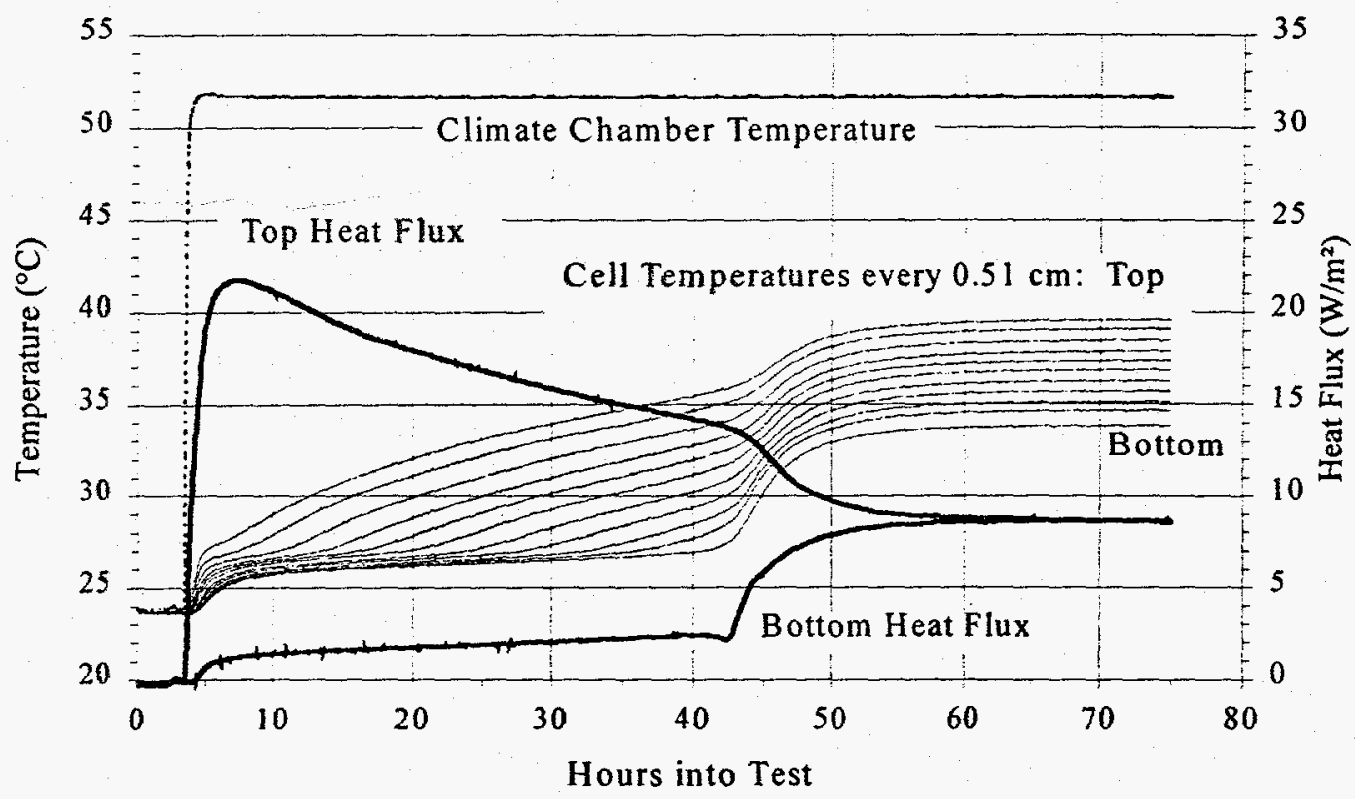

Fig. 3. Results for melting of the 2:1 mixture of PCM/perlite. 
at $52^{\circ} \mathrm{C}$ and the upper PCM layers. The phase change does not occur isothermally, however. Very important information obtained from the temperature profiles is that melting occurs from about 27 to $28^{\circ} \mathrm{C}$ for this PCM. The temperature at each level rises rapidly before phase change starts, especially for the upper layers. The smallest rates of increase of temperature occur during phase change in each layer, but they are not zero. When phase change in a layer is finished, temperatures rise a bit more rapidly. Only when all phase change is complete in the whole cell do the temperatures again rise rapidly, especially in the lower layers, to achieve the nearly uniform vertical spacing of temperatures shown at steady state when there is no more latent energy storage. Any slight discrepancy from equally spaced temperature profiles at steady state is attributed to variations from even spacing of thermocouples from top to bottom at the center of the support wires.

Figure 4 illustrates the concept of enhanced thermal performance, which is the application sought by the present work. Heat fluxes through the gypsum ceiling of the manufactured home test section are shown at locations under the center of each cell as well as under the fiberglass batts in the center of the joist space between the test cells (see Fig. 2). When steady heat fluxes are obtained for each system, an R-value can be assigned to each system by dividing the temperature difference across it by the heat flux through it. The results are shown in the figure, namely, an R-value of $2.4 \mathrm{~m}^{2} \cdot \mathrm{K} / \mathrm{W}$ for the fiberglass batt system, $2.3 \mathrm{~m}^{2} \cdot \mathrm{K} / \mathrm{W}$ for the $2: 1 \mathrm{RCR}$ system and $2.0 \mathrm{~m}^{2} \cdot \mathrm{K} / \mathrm{W}$ for the $6: 1$ $\mathrm{RCR}$ system. Thermal protection, as measured by these $\mathrm{R}$-values, is not much different from system to system, but is largest for the fiberglass batt system. Yet, while the PCMs are changing phase, the $6: 1$ system and, for a shorter time, the $2: 1$ system prevent heat from flowing through the ceiling much better than the fiberglass batt system.

When the PCM in both cells had melted and the steady-state temperature profiles had been established for the $52^{\circ} \mathrm{C}$ to $24^{\circ} \mathrm{C}$ difference between the climate and metering

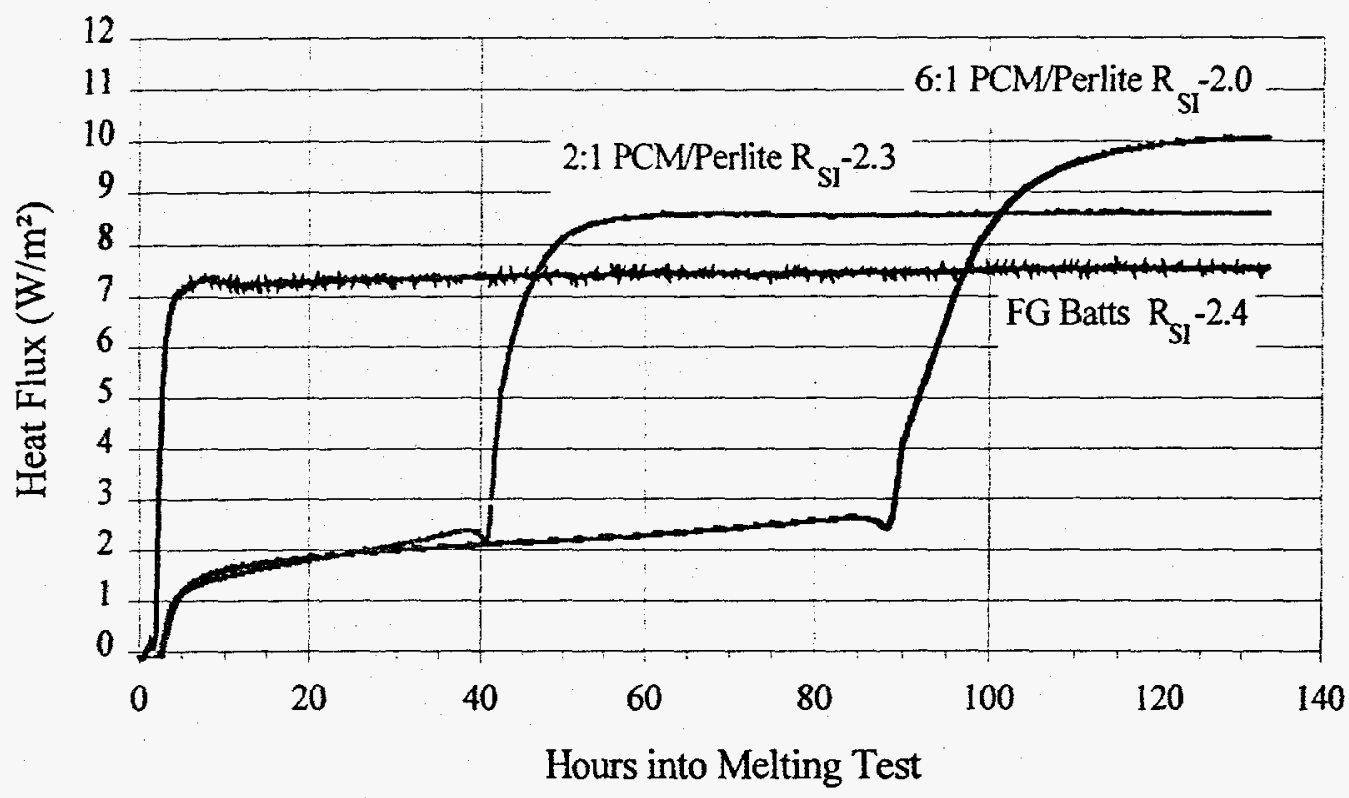

Fig. 4. Bottom heat fluxes and R-values for the PCM/perlite and fiberglass systems. 
chamber temperatures, freezing was initiated. Climate chamber temperature was brought to a steady $10^{\circ} \mathrm{C}$ as rapidly as possible. Fig. 5 shows temperatures and heat fluxes for the ensuing freeze in the 2:1 mixture. The climate chamber temperature does not undergo as perfect a step change for the freeze. Cooling is required to effect the change. We use direct expansion coils in the climate chamber and have a large compressor for rapid cooling and a small compressor to hold steady state against small loads. The large compressor overcooled the climate chamber slightly and there were a few hours of small climate chamber temperature fluctuations near $20 \mathrm{~h}$ into the test when the switch was made from the large to the small compressor.

The overcooling up to $6 \mathrm{~h}$ and fluctuations during switchover from 18 to $20 \mathrm{~h}$ are seen in the test cell temperatures and heat fluxes, especially the top heat flux. Just after $10 \mathrm{~h}$ there is also evidence of supersaturation in the heat fluxes and temperatures. The top heat flux goes through a maximum and the bottom a minimum not related to the fluctuations in the climate chamber temperature. In addition, the PCM seems to be subcooled below its equilibrium phase change temperature for a few hours just after $10 \mathrm{~h}$ but returns to the equilibrium curves by $15 \mathrm{~h}$.

A very important piece of information from the freezing curves is the temperature range in which freezing occurs. It is significantly below the melt range; in other words, this PCM exhibits hysteresis. For the $2: 1$ mixture, freezing occurred below $24^{\circ} \mathrm{C}$ and, for the $6: 1$ mixture, below $26^{\circ} \mathrm{C}$. Since the temperature difference between the climate chamber and the PCM during freezing was smaller than it was for melting, freezing takes longer: over $70 \mathrm{~h}$ for the $2: 1$ mixture vs. around $42 \mathrm{~h}$ for melting. For the 6:1 mixture,

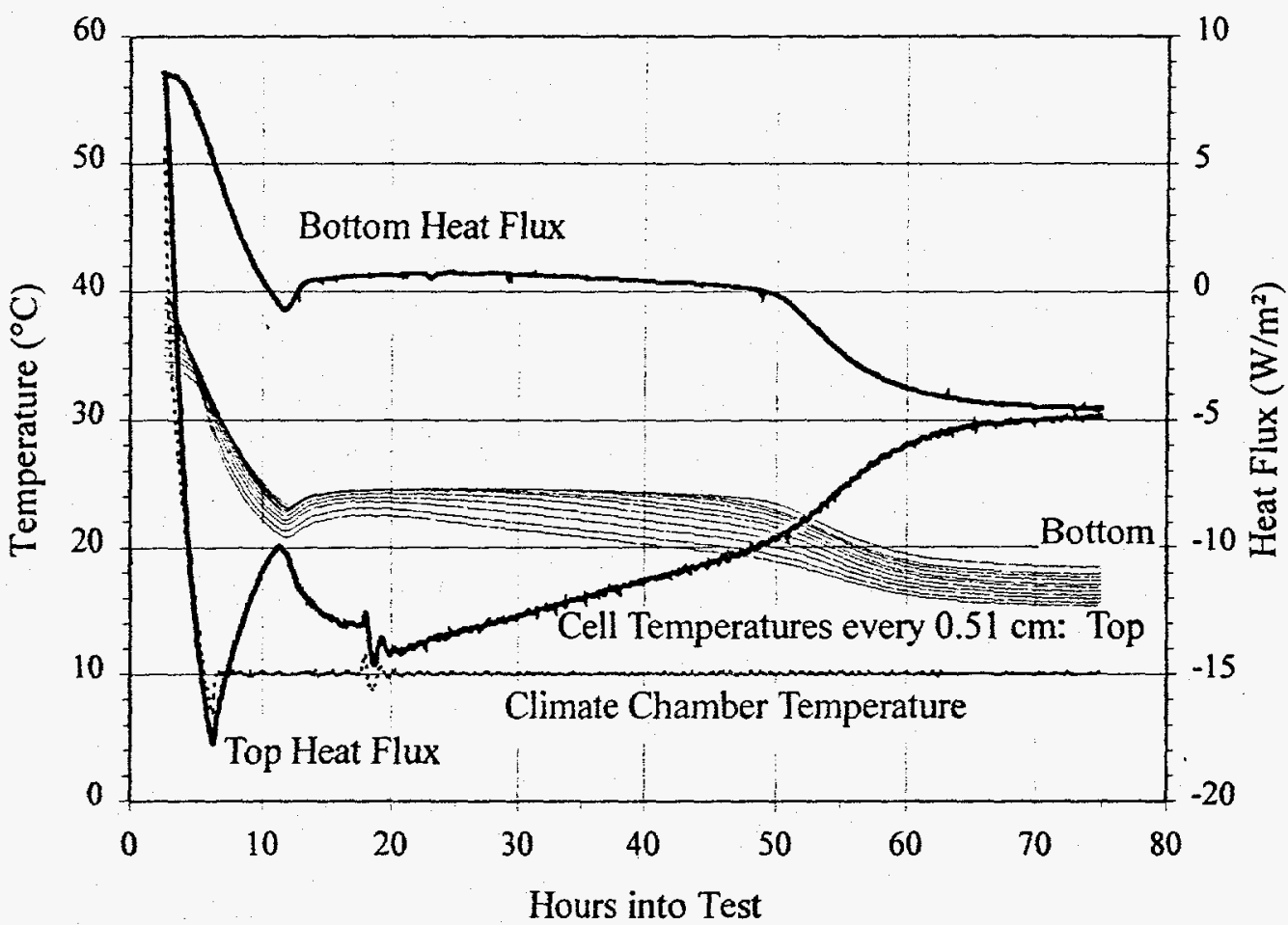

Fig. 5. Results for freezing of the 2:1 mixture of PCM/perlite. 
freezing took too long to wait for it to be completed before moving on to the diurnal tests, although by $95 \mathrm{~h}$ into the freezing test, the heat fluxes indicated that most of the freezing had occurred.

\section{DIURNAL CYCLE RESULTS}

A truer test of the potential for enhanced thermal performance with the candidate configurations is shown by their response to diurnal cycles. A diurnal cycle was programmed into the controller for the climate chamber temperature. Maximum daytime temperature was chosen as $66^{\circ} \mathrm{C}$ at each noon and minimum nighttime temperature as $10^{\circ} \mathrm{C}$ at each 4 a.m., respectively, to simulate the extremes of a desert climate. The first noon of the diurnal test occurred at 0 test hours following steady state at a climate chamber temperature of $52^{\circ} \mathrm{C}$ with all PCM melted. Variation between minimum and maximum temperatures was nearly sinusoidal but with less variation at night in agreement with observations of diumal temperature variations in outdoor tests.

Figure 6 shows the response to the cycles of the 2:1 mixture in the candidate configuration (two layers of XPS underneath and one layer above each test cell). The cycle shown started at $36 \mathrm{~h}$ into the test. The behavior in both cells was periodic stationary by this time on through all seven cycles that were simulated. For both cells, the top heat flux was in phase with the imposed temperature in the climate chamber. This is reasonable because only the attic space and a single $1.3 \mathrm{~cm}$ thick layer of XPS intervene and neither provides significant thermal mass.

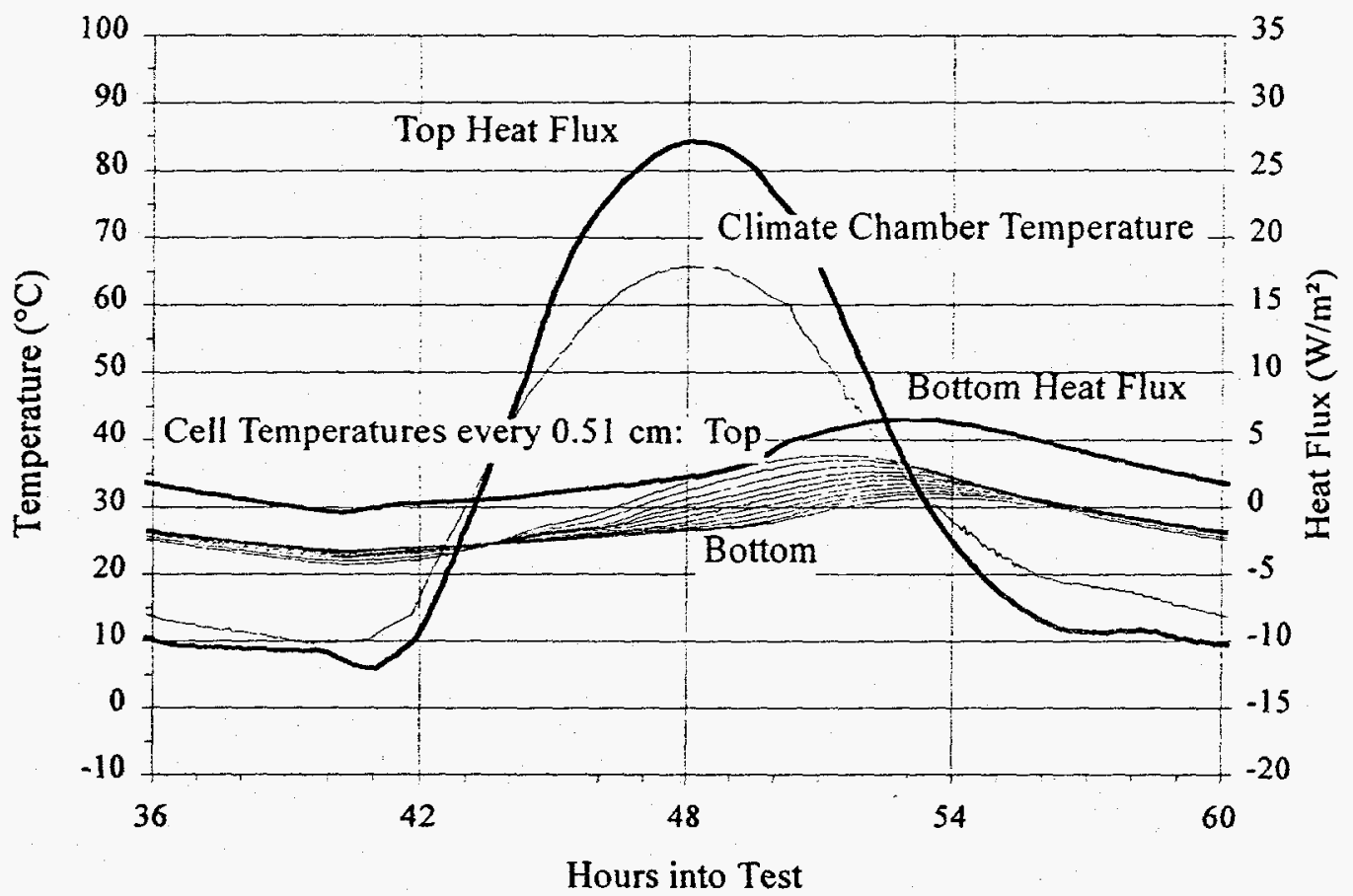

Fig. 6. Results for a diurnal cycle with the $2: 1$ mixture of $\mathrm{PCM}$ /perlite. 
The 2:1 configuration allows considerable phase change during each cycle and shows well the ability to enhance thermal performance. The bottom layer gets hotter than $29^{\circ} \mathrm{C}$ during daytime and cooler than $24^{\circ} \mathrm{C}$ at night so PCM in the cell can melt and freeze. The peak bottom heat flux is over $75 \%$ less than the peak top heat flux and is delayed nearly 6 hours. Hardly any heat flows into the space under the cell (inside) at night whereas the top heat flux goes negative, allowing energy stored in phase change to flow to the upper chamber (outside) as desired.

Results for the 6:1 configuration are not shown but were consistent with the greater amount of phase change material. The temperatures for the lower layers stayed around $27^{\circ} \mathrm{C}$ day and night. The top temperatures indicated that phase change was happening only near the top. Peak shaving was nearly perfect: the bottom heat flux levelled out at less than $10 \%$ of the peak heat flux and presented a small and constant heat load on the space below the PCM/perlite mixture (inside) despite the severe conditions imposed in the climate chamber (outside).

To focus on the thermal performance enhancement capabilities of two configurations of PCM/perlite relative to fiberglass batts, the bottom heat fluxes are of special interest. They are compared in Fig. 7 from 36 to $60 \mathrm{~h}$ into the test. Climate chamber temperatures are also shown and are useful to establish a reference for phase shifts. For this cycle, the fiberglass batt system, despite having the highest steady-state R-value of the three systems, has the highest peak heat flux and it is shifted only about $1 \mathrm{~h}$ relative to the imposed temperatures. The 2:1 RCR system's peak is $58 \%$ of that for fiberglass (reduced $42 \%$ ) and it is delayed $5 \mathrm{~h}$. As much as there is any peak left for the $6: 1$ system,

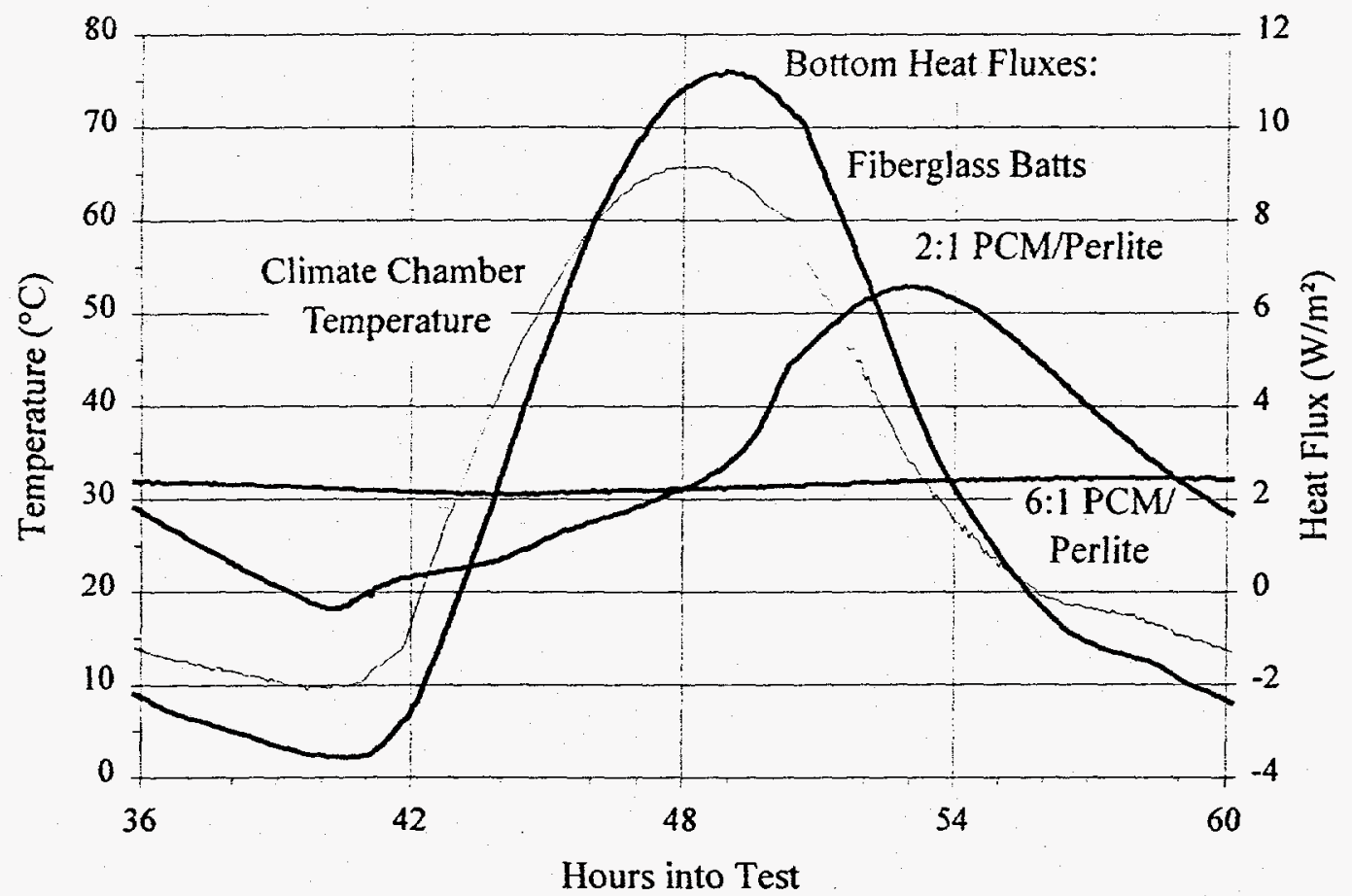

Fig. 7. Comparison of bottom heat fluxes for fiberglass batts, $2: 1 \mathrm{PCM} /$ perlite and 6:1 $\mathrm{PCM}$ /perlite during a diurnal cycle. 
it is $22 \%$ of the fiberglass peak (reduced $78 \%$ ) and is delayed $10 \mathrm{~h}$. Because the fiberglass batt system has no significant thermal mass, it offers no peak load reduction nor significant peak load shift like the RCR systems.

A quantitative measure of enhanced thermal performance with the RCR systems is obtained from the total heat flows into the metering chamber. On a daily basis, for the climate chamber temperature cycle shown in Figs. 6 and 7, the fiberglass batt system allowed $294 \mathrm{~kJ} / \mathrm{m}^{2}$ of heat to flow downward, which was removed by the metering chamber cooling system in order to maintain the constant temperature of $24^{\circ} \mathrm{C}$ there. To maintain this constant temperature at night, $94 \mathrm{~kJ} / \mathrm{m}^{2}$ needed to be supplied. These daily heat flows per unit area into the metering chamber are obtained by integrating the area above the zero heat flux level. The area below zero is the heat flow out of the metering chamber. For the $2: 1 \mathrm{RCR}$ system, heat flow downward is only $229 \mathrm{~kJ} / \mathrm{m}^{2}, 22 \%$ less than with the fiberglass batt system. No significant amount of heat flows out of the conditioned space at night. For the $6: 1 \mathrm{RCR}$ system, the total heat flow is $199 \mathrm{~kJ} / \mathrm{m}^{2}, 32 \%$ less than for the fiberglass; as seen in Fig. 7 , it is virtually a constant but small heat load.

\section{PREDICTIONS WITH THE COMPUTER PROGRAM HEATING}

From the results with diurnal cycles, the $2: 1 \mathrm{PCM}$ perlite mixture seems to contain enough phase change material to thermally protect the space below the test cells, but not so much that the actual amount of PCM in the system is underutilized, like happens for the 6:1 mixture. In order to do engineering design to specify the configuration of PCM/perlite and conventional insulation that achieves optimum thermal performance enhancement, a model is needed to do parametric variations. The focus in this section is on results obtained for the 2:1 RCR system with HEATING, a finite difference three-dimensional transient thermal conduction program. The purpose of this modeling was to reproduce the temperatures in the 2:1 test cell and its top and bottom heat fluxes, thereby verifying our understanding of the heat transfer and phase change phenomena occurring in it.

This verification is the first step in the more ambitious modeling effort needed to have a design tool. To optimize the amount of PCM in a RCR system as well as the amount of conventional insulation and its placement relative to the PCM, a whole building model is required. Typical whole building modeling programs, such as DOE-2 [5, 6$]$, use one-hour time steps for the response of the building to applied conditions. To interface with such programs, subroutines to handle the effects of phase change would need to be written and merged with the main program. Our results with diurnal cycles show that significant effects are occurring over one-minute rather than one-hour time steps. The size of the finite time and spatial steps used by HEATING can be adjusted to suit the application. Whole building modeling with phase change algorithms is beyond the scope of the present study.

For the present, the objective is to model the specific configuration of the $2: 1$ RCR system under the conditions that were imposed in the melting, freezing and diumal cycle experiments. HEATING was provided with a description of the geometry, reduced to a one-dimensional series of material layers: a $1.3 \mathrm{~cm}$ thick layer of XPS; a $0.3175 \mathrm{~cm}$ 
thick layer of methylmethacrylate; the $5.08 \mathrm{~cm}$ deep PCM/perlite; another $0.3175 \mathrm{~cm}$ thick layer of methylmethacrylate; two $1.3 \mathrm{~cm}$ thick layers of XPS; and a $0.9525 \mathrm{~cm}$ thick gypsum board. Temperatures measured on the top of the top layer of XPS and on the bottom surface of the gypsum board were the boundary conditions for the model.

Thermophysical properties were assumed to be constant with temperature.

Density was determined to be $266.7 \mathrm{~kg} / \mathrm{m}^{3}$ by weighing a known volume on an electronic balance. Other values were estimated from the measurements for the melt and freeze experiments and averaged. The apparent thermal conductivity was $0.076 \mathrm{~W} / \mathrm{m} \cdot \mathrm{K}$ from the steady-state heat fluxes and temperature differences across the test cell. The sensible heat capacity was $2.35 \mathrm{~kJ} / \mathrm{kg} \cdot \mathrm{K}$ from the steady-state change in stored energy vs. temperature. Total energy absorbed for the complete phase changes less a correction for sensible heat stored yielded a latent heat capacity of $138 \mathrm{~kJ} / \mathrm{kg}$. As noted previously, the temperature range over which the melting occurred was observed from the measurements to be 27 to $28^{\circ} \mathrm{C}$. The freezing range was more difficult to estimate: 23 to $24^{\circ} \mathrm{C}$ was established by trial-and-error. For the diurnal cycles, the average of these ranges, 25 to $26^{\circ} \mathrm{C}$, was used. HEATING has a subroutine for isothermal phase change that handles latent energy storage separately from sensible storage. Temperature changes in an element are suspended until phase change is complete. Here, where phase change occurred over a range of temperatures, the latent storage subroutine was not used; sensible heat capacity was augmented in the desired range of temperatures by a triangular function with a total area equal to the desired latent heat capacity.

For the melting and freezing of the 2:1 mixture of PCM/perlite, the measured XPS cover and gypsum temperatures, which were the boundary conditions, were almost constant. The predicted temperatures in the test cells reflected the phase change. One feature of the predictions was that cell temperatures went more abruptly to the slow rate of increase during phase change and to the high rate of increase at the end of phase change. This is likely due to the triangular profile used for latent heat capacity; a bell-shaped profile would allow more gradual changes in slope. Another feature was that the temperatures, as well as the heat fluxes, took slightly longer to show the end of phase change in the freezing predictions compared to the experiments. The same average value for total heat capacity was used to model both melting and freezing, but freezing, with its smaller overall driving temperature difference, seemed more sensitive to the total heat capacity.

In the freezing predictions the top heat flux responded to overcooling when the large compressor was used at the beginning of the test. The top heat flux was affected by the temperature fluctuation when the small compressor took over the load. There was no evidence in the predicted top heat flux of the maximum between these compressor effects. Recall that this maximum in Fig. 5 was attributed to supersaturation. No attempt was made to model supersaturation phenomena during freezing. The lack of the maximum in the predictions is further proof of the presence of supersaturation in the experiments.

Figure 8 shows the results of the predictions for the cycle from 36 to $60 \mathrm{~h}$ into the diurnal test. Besides ignoring supersaturation effects observed during freezing, the model uses a range of phase change temperatures that is the average of the melting and freezing ranges. This effectively ignores the hysteresis exhibited by this PCM. Hence, more significant differences between the measured and predicted temperatures and heat fluxes 


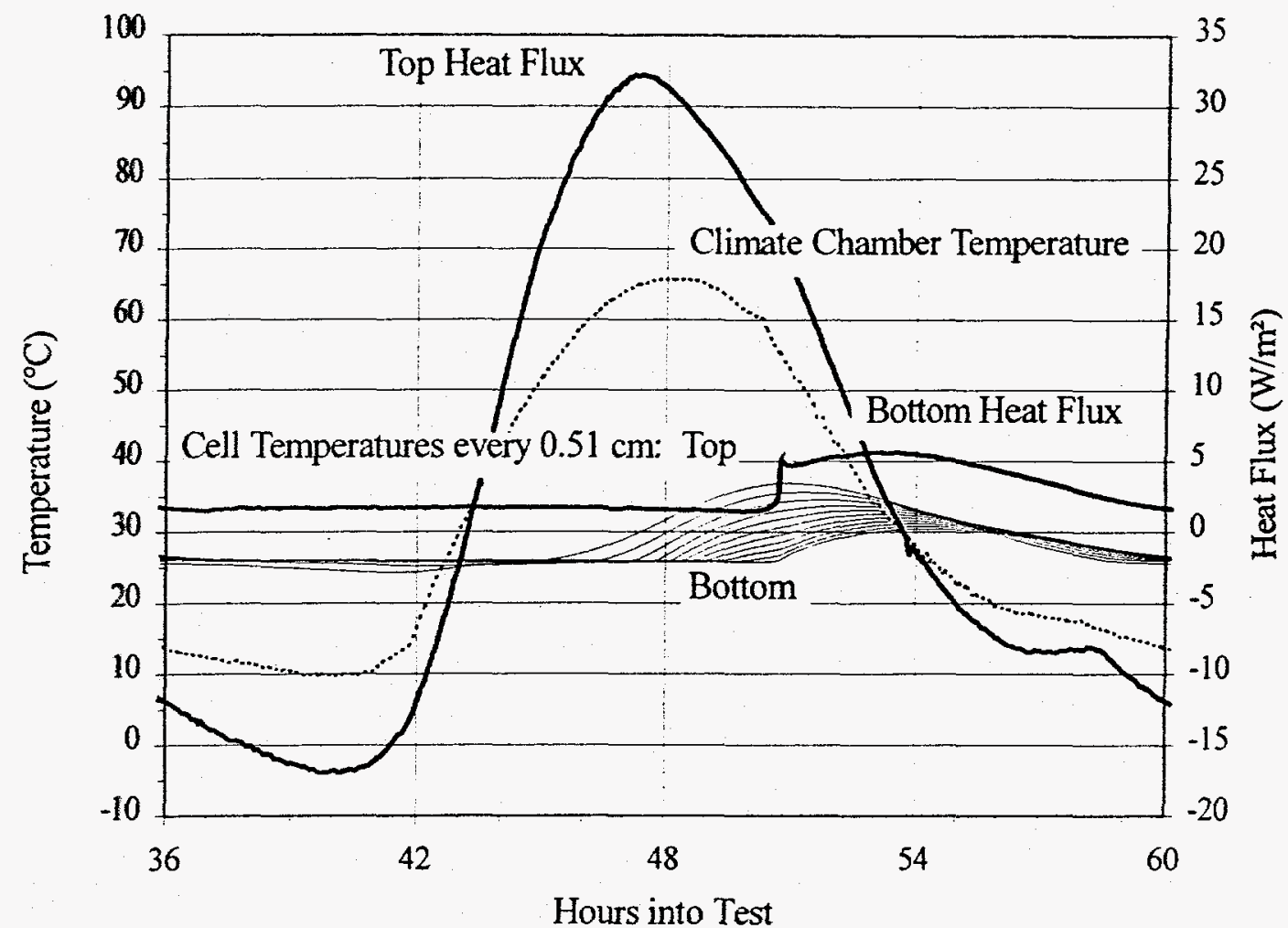

Fig. 8. Predictions of HEATING for a diurnal cycle with the 2:1 mixture of PCM/perlite.

are expected than for the simpler melting and freezing cases. The predicted temperatures during the melting part of the cycle do not get as warm as the measured values in Fig. 6 . Nor do they get as cool as the measured temperatures during the freezing part. Since the phase change temperature was moved down from the actual melting range and up from the actual freezing range, the predictions are consistent.

Without a model for supersaturation during freezing, less PCM seems to be changing phase in the predictions compared to the measurements. Hence, the predicted temperatures near the bottom of the test cell are bunched together, especially at night. This explains the discontinuity at $51 \mathrm{~h}$ in the bottom heat flux. It is difficult to produce a smooth curve for a heat flux from the difference of two temperatures almost equal in value but changing at different rates. Regardless, the magnitude and range of variation of the bottom heat flux are remarkably close to the measurements. Since the top temperatures are slightly lower than the measured ones, the top heat flux peaks at a higher value and bottoms out at a lower value than the measurements. Even though the top and next to top temperatures in the cell peak slightly after the imposed temperature on top of the XPS, the top heat flux, which is computed from their difference, peaks slightly before. This is again due to the difficulty of predicting a heat flux from the difference of two approximately equal temperatures with slightly different time variations.

The objective of the modeling with HEATING was to prove that we understand the phenomena involved in using the PCM available for the experiments as part of an 
RCR system. To summarize how well we have met this objective, Fig. 9 compares directly the bottom heat fluxes predicted and measured for the melting, freezing and diurnal cycles with the 2:1 system. As stated above, HEATING does not include a delay in the onset of freezing until temperatures are lower than equilibrium values (supersaturation) and a difference between the melting and freezing temperatures (hysteresis). Even so, the magnitude and variation of the predicted bottom heat fluxes are similar enough to the measurements to allow the scheme used by HEATING to form the basis of a subroutine for performance of RCR systems in a whole house model.

\section{CONCLUSIONS AND RECOMMENDATIONS}

Carefully controlled and well documented experiments have been done with two configurations of $\mathrm{PCM} /$ perlite mixtures between conventional insulation to decrease the heat load on a conditioned space relative to that with conventional insulation. The configurations with PCM are called RCR systems. The RCR systems and the conventional system had about the same R-value, which is a valid measure of thermal

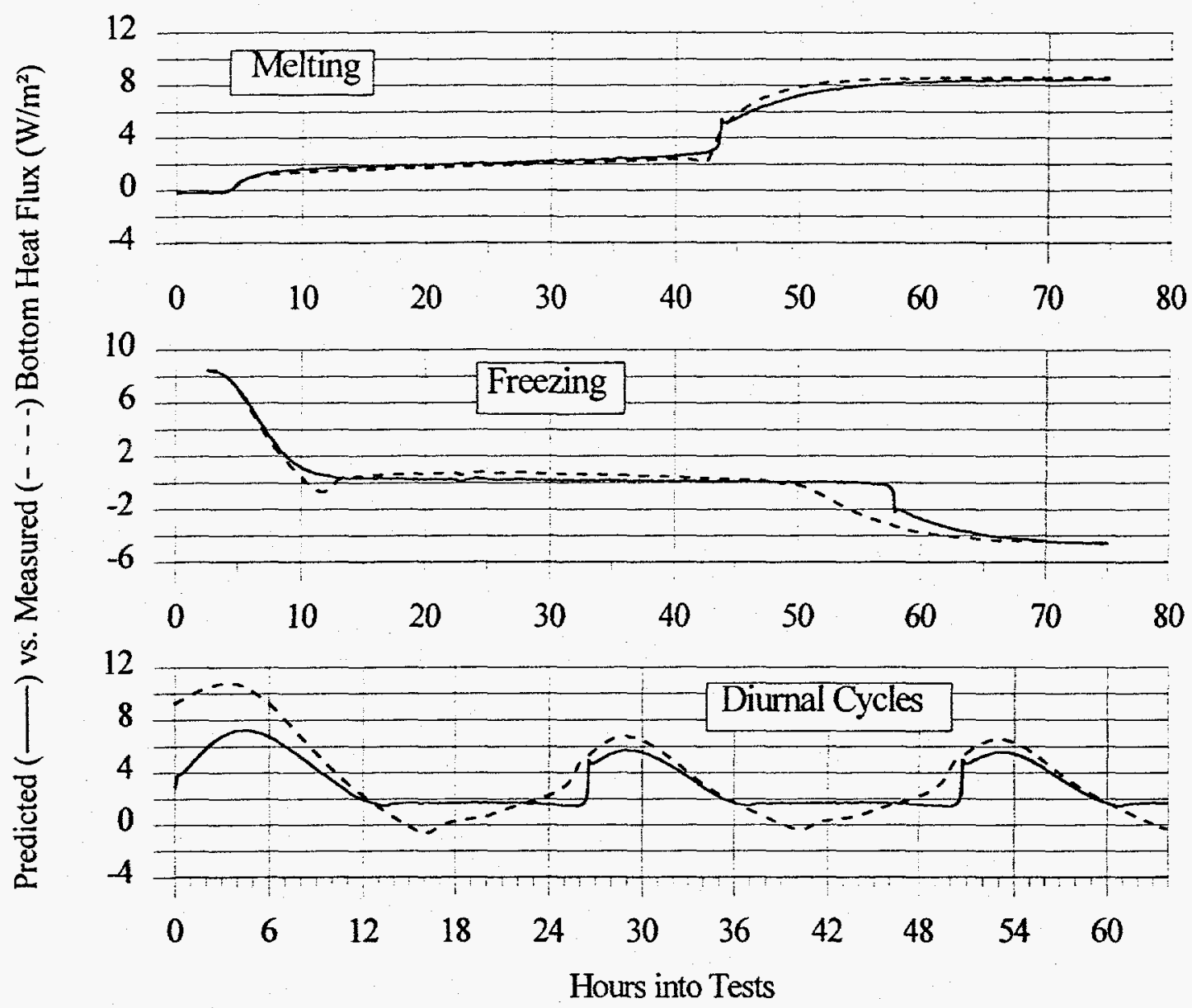

Fig. 9. Predicted vs. measured bottom heat fluxes for the 2:1 mixture of PCM/perlite. 
performance only for steady state. The 2:1 PCM/perlite mixture and the 6:1 PCM/perlite mixture, both on a weight basis, when sandwiched between extruded polystyrene insulation, accomplished better dynamic thermal performance than a fiberglass batt insulation system. The 2:1 RCR system seemed to have enough PCM to be effective and involve a much larger fraction of its PCM in diurnal freezing and melting than the 6:1 RCR system. It is a good starting point for engineering design of an optimum RCR system.

During one day after periodic stationary behavior had been established in the diurnal cycle tests, the $2: 1$ RCR system required $78 \%$ of the corresponding total cooling per unit ceiling area of the fiberglass system ( $22 \%$ less). Its peak heat flux was $58 \%$ of the peak for the fiberglass system (42\% less) and it occurred four hours later. The $6: 1$ RCR system required $68 \%$ of the fiberglass system's total cooling ( $32 \%$ less). The profile was essentially flat at a level that was $21 \%$ of the peak fiberglass heat flux $(79 \%$ less).

The results from the $2: 1 \mathrm{RCR}$ system were reproduced with the computer program HEATING to prove that we know the relevant mechanisms and thermophysical properties of the PCM used in the experiments. Even without a model for the supersaturation and hysteresis that this material exhibited, HEATNG reproduced the heat fluxes to the conditioned space in the experiments accurately enough to mirror the enhanced thermal performance of the RCR system compared to a conventional system. The modified sensible heat capacity that was used in HEATING is an accurate and flexible way to account for phase change effects in the material used and could be incorporated into a subroutine to compute hourly phase change effects for whole building models.

The experiments were done with PCM/perlite mixtures sealed in small methylmethacrylate boxes and covered top and bottom by XPS. Besides isolating the hygroscopic PCM from atmospheric moisture, the boxes allowed precise placement of the instrumentation used to follow the phase change effects. The XPS gave high R-value per unit thickness. A more practical prototype configuration, such as PCM hermetically sealed with perlite in plastic pouches or in perlite insulation board and placed between layers of batts or blown-in insulation, should be tested over a larger cross section. A good candidate test section for such a test is the whole attic cavity of the manufactured home test section used in the present work. Use of a PCM that does not exhibit supersaturation and hysteresis would make interpretation of the results easier.

Whole building modeling programs like DOE-2 use hourly steps to calculate annual energy use. Models of phase change phenomena require steps no longer than a minute. For use in design of RCR systems for whole buildings, a model for annual energy use should be run in a program with a phase change algorithm in order to optimize the RCR configuration for cost savings in the climate in which it will perform.

Current energy codes recognize the thermal benefits of massive systems for sensible heat storage. If the advantages of the lighter PCM-based systems for latent heat storage are recognized, extensive marketing opportunities should be available. This should be true especially in manufactured housing where massive systems are too costly. Discussions are ongoing with potential manufacturers and distributors of RCR systems to determine the economic feasibility of the concept for manufactured housing and other applications. 


\section{REFERENCES}

[1] Lane, G. A., Solar Heat Storage: Latent Heat Materials Chemical Rubber Co., Boca Raton, Florida, 1983.

[2] Kedl, R. J., "Wallboard with Latent Heat Storage for Passive Solar Applications," Oak Ridge National Laboratory Report ORNL/TM-11541, Oak Ridge National Laboratory, Oak Ridge, Tennessee, 1991.

[3] Tomlinson, J. J., and Heberle, D., "Analysis of Wallboard Containing a Phase Change Material," Proceedings of the 25th Intersociety Energy Conversion Engineering Conference, Vol. 4, Reno, Nevada, 1990.

[4] Childs, K. W., "Heating 7.2 Users' Manual," Oak Ridge National Laboratory Report ORNL/TM-12262, Oak Ridge National Laboratory, Oak Ridge, Tennessee, 1993.

[5] "DOE-2 Reference Manual, Version 2.1A," Lawrence Berkeley National Laboratory Report LBL-8706, Rev. 2, Lawrence Berkeley National Laboratory, Berkeley, California, 1981.

[6] “DOE-2 Supplement, Version 2.1E," Lawrence Berkeley National Laboratory Report LBL-34947, Lawrence Berkeley National Laboratory, Berkeley, California, 1993. 